\section{JURNAL PENELITIAN PENDIDIKAN IPA}

http://jppipa.unram.ac.id/index.php/jppipa
e-ISSN : 2407-795X

p-ISSN : 2460-2582

Vol 2, No, 2

Juli 2016

\title{
ANALISIS KANDUNGAN LOGAM BERAT Pb PADA SEDIMEN dan KERANG DARAH (Genus: Anadara) di PERAIRAN PANTAI LABUHAN TERENG KABUPATEN LOMBOK BARAT
}

\author{
Meyla Fitri handayani ${ }^{1}$, Muhlis, Erin Ryantin Gunawan ${ }^{3}$ \\ Magister Pendidikan IPA Program Pasca Sarjana Universitas Mataram ${ }^{123}$ \\ Email: meylafitrihandayani@gmail.com
}

\begin{abstract}
Key Words
Blood

cockle,

sediment,

acumulation,

lead

Abstract

The aims of this research are to analyze the content of Lead in blood cockle (Genus: Anadara) at West Lombok Labuhan Tereng coastal waters. The content of lead in sediment and clams was analysis at Mataram University Analytical Laboratory by using wet digestion method and measured using atomic absorption spectrophotometer $(A A S)$ in $283.3 \mathrm{~nm}$ wavelength. The results then compared with the sediments and clams standards applicable. Results of Pb in the sediment measurements show that the highest lead levels is $30.66 \mathrm{mg} / \mathrm{kg}$ found in around Dusun Cemara coast. The results obtained are still at the level targets under Dutch Quality Standards for Metals in sediments (IADC / CEDA), 1997. The highest Pb levels in blood clams is 13,075 mg/kg contained by a medium-sized $(3.08 \mathrm{~cm})$ of species A. antiquata around Kebon Talo estuary. These results are indicate that the levels of $\mathrm{Pb}$ in blood cockle is already distant exceeded the threshold of consumption under Indonesian National Standar, 2009 which is equals to $1.5 \mathrm{mg} / \mathrm{kg}$, so the clams blood in coastal waters Labuhan Tereng should not be consumed greatly overheated because the accumulative character of Pb can be harmful for health.
\end{abstract}

\begin{tabular}{|c|c|}
\hline Kata Kunci & Abstrak \\
\hline $\begin{array}{l}\text { Blood } \\
\text { cockle, } \\
\text { sediment, } \\
\text { acumulation, } \\
\text { lead }\end{array}$ & $\begin{array}{l}\text { Penelitian ini bertujuan untuk menganalisis kandungan logam berat Pb pada kerang } \\
\text { darah (Genus: Anadara) di perairan pantai Labuhan Tereng Kabupaten Lombok Barat. } \\
\text { Analisis kandungan Pb pada sedimen dan kerang darah dilakukan di Laboratorium } \\
\text { Analitik Universitas Mataram dengan menggunakan metode destruksi basah dan diukur } \\
\text { dengan menggunakan spektrofotometer serapan atom (SSA) dengan panjang } \\
\text { gelombang } 283,3 \mathrm{~nm} \text {. Hasil yang didapat kemudian dibandingkan dengan baku mutu } \\
\text { yang berlaku untuk sedimen dan kerang. Hasil pengukuran kadar Pb pada sedimen } \\
\text { menunjukkan bahwa kadar Pb tertinggi terdapat pada pesisir sekitar dusun Cemara } \\
\text { yaitu sebesar } 30.66 \mathrm{mg} / \mathrm{kg} \text {. Hasil yang diperoleh masih berada pada level target } \\
\text { menurut Dutch Quality Standars for Metals in Sediments (IADC/CEDA), 1997. Kadar } \\
\mathrm{Pb} \text { tertinggi pada kerang darah terdapat pada spesies A. antiquata berukuran sedang } \\
\text { (3.08 cm) dilokasi sekitar muara Kebon Talo yaitu } 13.075 \mathrm{mg} / \mathrm{kg} \text {. Hasil ini } \\
\text { menunjukkan bahwa kadar Pb pada kerang sudah jauh melebihi ambang batas } \\
\text { konsumsi menurut Standar Nasional Indonesia, } 2009 \text { yaitu sebesar } 1.5 \text { gr/kg, sehingga } \\
\text { kerang darah di perairan pantai Labuhan Tereng tidak boleh dikonsumsi secara } \\
\text { berlebih karena sifat Timbal yang akumulatif dan dapat membahayakan kesehatan. }\end{array}$ \\
\hline
\end{tabular}

\section{PENDAHULUAN}

Logam berat merupakan elemen kimiawi metalik dan metaloida, memiliki bobot atom dan bobot jenis yang tinggi, yang dapat bersifat racun bagi mahluk hidup (SNI, 2009). Logam berat masuk ke lingkungan laut 
kebanyakan terjadi akibat adanya buangan limbah industri yang masuk melalui tiga cara yaitu: pembuangan limbah industri yang tidak dikontrol, lumpur minyak yang juga mengandung logam berat dengan konsentrasi tinggi, serta adanya pembakaran minyak hidrokarbon dan batubara di daratan (Payung dkk, 2013). Salah satu logam berat yang bersifat toksik dan dapat mencemari lingkungan perairan yaitu $(\mathrm{Pb})$.

Bahan pencemar berupa logam berat $\mathrm{Pb}$ mencemari perairan yang masuk dari darat biasanya berasal dari limbah industri hasil pembakaran bahan bakar kendaraan bermotor, tumpukan sampah, dan wisata bahari. Namun, banyak penelitian yang menyatakan bahwa salah satu sumber pencemaran $\mathrm{Pb}$ yang paling tinggi bersumber dari aktifitas perkapalan dan kegiatan pelabuhan. Diperkuat oleh penelitian Amin, dkk (2011), Siaka (2008), dan Lubis \& Challkuddin (2008) yang menyatakan bahwa sumber pencemar $\mathrm{Pb}$ masuk keperairan diperkirakan kebanyakan berasal dari aktivitas kapal-kapal nelayan, kapal-kapal penyebrangan dan bahan pencemar yang terbawa oleh arus. Hasil penelitian Tampubolon dkk (2013) juga menyatakan bahwa Tingginya konsentrasi logam $\mathrm{Pb}$ di danau salah satunya dapat berasal dari kegiatan buangan sisa bahan bakar kapal motor, cat kapal, dan kegiatan wisata. Hasil Penelitian Wahab dan Mutmainnah (2005), juga menyatakan bahwa sumber bahan pencemar $\mathrm{Pb}$ dapat berasal dari limbah minyak dari kapal.
Pelabuhan Lembar merupakan salah satu pelabuhan terbesar yang berlokasi di perairan pantai Labuhan Tereng Kabupaten Lombok Barat. Logam berat $\mathrm{Pb}$ yang berasal dari segala aktivitas manusia (terutama aktifitas pelabuhan) akan masuk ke dalam perairan turun dan mengendap pada dasar perairan kemudian akan terakumulasi ke dalam sedimen, dan hal ini akan menyebabkan organisme yang mencari makan di dasar perairan seperti udang, rajungan, dan kerang akan memiliki peluang yang besar untuk terpapar logam berat yang telah terikat di dasar perairan dan membentuk sedimen.

Perairan pantai Labuhan Tereng dimanfaatkan oleh para nelayan sekitar untuk mencari kerang ketika air sedang surut. Para nelayan menangkap kerang dengan alat-alat sederhana berupa sabit, serokan, dan menggunakan tangan. Hasil tangkapan yang mereka peroleh kemudian dijual untuk memenuhi kehidupan sehari-hari. Lokasi penangkapan kerang yang tidak terlalu jauh dari pelabuhan memungkinkan kerang terpapar oleh logam berat hasil dari aktifitas perkapalan. Sifat kerang yang sesil dan dengan mobilitas yang rendah membuat kerang akan sulit menghindar dari paparan logam berat $\mathrm{Pb}$ pada perairan. Menurut Nurjannah dkk (1999), Logam berat dapat terkonsentrasi melalui rantai makanan dan terakumulasi dalam organisme yang bersifat benthic seperti pada jenis bivalvia. Kelompok bivalva diketahui dapat mengakumulasikan jenis-jenis polutan sampai pada jumlah yang 
membahayakan bagi konsumen. Hal ini berhubungan erat dengan sifat filter feeder yang dimilikinya dan cara hidupnya yang relatif menetap, sehingga kecil kemungkinannya untuk menghindar dari perubahan lingkungan perairan yang membahayakan.

Berdasarkan hasil observasi, terdapat 16 jenis kerang di perairan pantai Labuhan Tereng, salah satunya berasal dari genus Anadara (kerang darah). Kerang darah merupakan salah satu sumber daya ekonomis penting, karena merupakan sumber makanan yang berprotein tinggi dan sangat digemari oleh masyarakat. Namun berdasarkan beberapa penelitian yang telah dilakukan menyatakan bahwa kerang darah dapat mengakumulasi logam berat jauh lebih tinggi dibandingkan kandungan logam berat didalam air. Hasil penelitian Umbara \& Heny (2006) yang menyatakan bahwa kerang Anadara granosa dapat dijadikan bioindikator karena kemampuan mengakumulasi yang direpresentasikan oleh nilai faktor bioakumulasi konsentrasi maksimal sebesar 835,75 kali dibandingkan kosentrasinya dalam air laut dan kejadian polusi dapat terdeteksi menggunakan bioindikator Anadara granosa walaupun hanya berlangsung 1 hari.

Keracunan timbal akut pada manusia menyebabkan disfungsi yang parah pada ginjal, sistem reproduksi, hati, otak dan sistem syaraf pusat yang dapat menimbulkan penyakit maupun kematian. Keracunan timbal dari pajanan lingkungan dapat menyebabkan keterbelakangan mental pada anak. keracunan timbal ringan dapat menyebabkan anemia yang menyebabkan korban menderita sakit kepala dan sakit otot, dan kadang merasa lelah dan umumnya mudah tersinggung (Manahan, 2000). Karna dampak logam berat $\mathrm{Pb}$ yang berbahaya bagi kesehatan manusia yang mengkonsumsinya, maka sangat penting untuk mengetahui tingkat pencemaran logam berat di perairan pantai Labuhan Tereng Kabupaten Lombok Barat.

\section{METODE}

Penelitian ini dilakukan selama bulan Juli-September 2015 dengan tiga kali pengambilan sampel di Perairan Labuhan Tereng Kabupaten Lombok Barat.

\section{Pengambilan sampel bivalvia}

Penelitian ini dilakukan di tiga stasiun pengambilan sampel pada Pesisir Labuhan Tereng (Gambar 1) yang meliputi LPS-I (844'3.01"S-116 $\quad 3 ' 28.73 " E), \quad$ LPS-II (844'0.24"S- $\left.116^{\circ} 3^{\prime} 54.98 " E\right)$, dan LPS-III ( $\left.8^{\circ} 43^{\prime} 51.58 " S-116^{\circ} \quad 4^{\prime} 50.91 " E\right) . \quad$ Masingmasing stasiun pengamatan diukur parameter fisika (Kedalaman air ketika surut, kedalaman air ketika pasang, suhu, dan fraksi sedimen) dan kimianya ( $\mathrm{pH}$ dan salinitas).

Penentuan stasiun pengamatan pada lokasi penelitian didasarkan pada pendekatan konseptual dengan melakukan survey terhadap kegiatan yang diperkirakan sebagai sumber pencemaran di lingkungan perairan dan lokasi para nelayan mengambil kerang. 


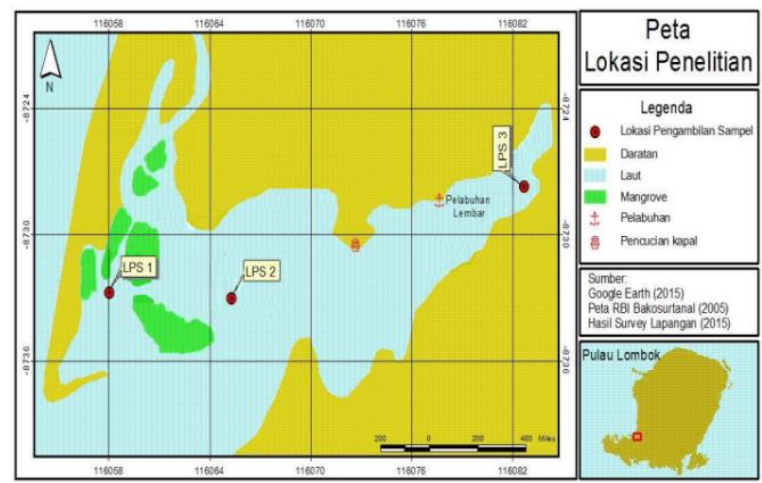

Gambar 1. Peta Lokasi penelitian Kelimpahan kerang darah (Genus: Anadara) di perairan Pantai Labuhan Tereng Kabupaten Lombok Barat.

Sampel sedimen diambil pada bagian permukaan $(0-5 \mathrm{~cm}) \pm 200$ gr dengan menggunakan sekop dan dimasukan ke dalam plastik dan diberi kertas label dengan menggunakan spidol permanen pada sampel, selanjutnya disimpan dalam coolbox. Kerang darah diambil ketika air laut surut dengan menggunakan alat tangkap sederhana atau tangan, kemudian dimasukan ke dalam plastik dan dimasukkan kedalam coolbox. Sampel sedimen dan kerang darah dibawa ke laboratorium untuk dianalisis. Analisis logam berat baik pada sedimen, maupun kerang darah (Anadara) ukuran besar $(>3 \mathrm{~cm})$ dan kecil $(<3 \mathrm{~cm})$, dilakukan melalui tiga tahap, yaitu preparasi, destruksi basah dan pengukuran menggunakan Atomic Absorption Spectrofotometri (AAS).

\section{Analisis Data}

Untuk mengetahui nilai biokonsentrasi logam organisme dengan sedimen maka digunakan indeks faktor konsentrasi (Connel dan Miller, 1995):

Faktor konsentrasi $=\frac{\text { kadar logam berat pada daging }}{\text { kadar logam berat pada sedimen }}$
PTWI (Provisional Tolerable Weekly Intake) adalah jumlah asupan kontaminan logam berat pada makanan yang dapat ditoleransi untuk seminggu sehingga tidak membahayakan kesehatan. Nilai PTWI untuk $\mathrm{Pb}$ yaitu sebesar $0.025 \mathrm{mg} / \mathrm{kg}$ (SNI 2009). Penentuan batas aman konsumsi dilakukan dengan mengacu pada nilai PTWI sehingga diperoleh batas aman kerang yang boleh dikonsumsi. Batas aman konsumsi kerang dapat dihitung sebagai berikut:

PTWI $=\frac{\text { baku mutu }}{\text { kadar logam dalam daging }}$

\section{HASIL DAN PEMBAHASAN}

Hasil analisis logam berat $\mathrm{Pb}$ menggunakan AAS pada sedimen diketiga stasiun penelitian dapat diihat pada gambar 2 . Rata-rata $\pm \mathrm{SD}$ kadar $\mathrm{Pb}$ pada sedimen tertinggi terdapat pada LPS-I yaitu 13.481 $\mathrm{mg} / \mathrm{kg} \pm 12.18$, dan yang terendah terdapat pada LPS-II yaitu $8.32 \mathrm{mg} / \mathrm{kg} \pm 11.86$. LPS-I merupakan daerah yang paling jauh dari pelabuhan namun memiliki kadar $\mathrm{Pb}$ lebih tinggi. Amriani dkk (2011),

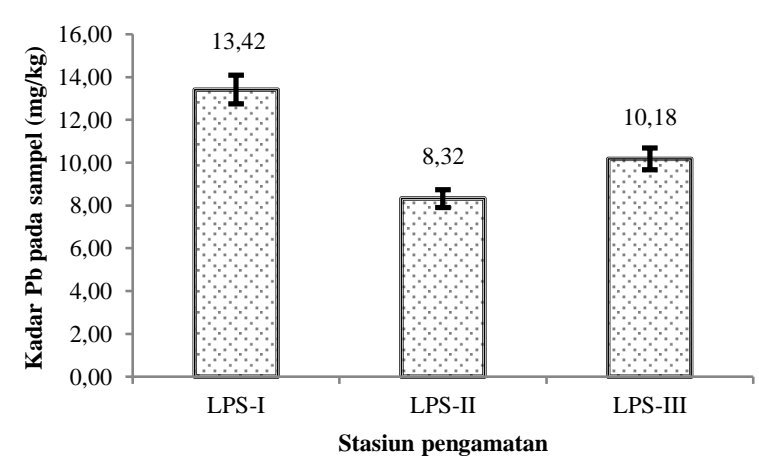

Gambar 2. Kandungan logam berat $\mathrm{Pb}$ pada sedimen di perairan pantai Labuhan Tereng Kabupaten Lombok Barat. 
menyatakan bahwa pada air laut logam $\mathrm{Pb}$ masih bisa bergerak bebas akibat pengaruh arus, pasang surut dan gelombang sehingga terjadinya pengenceran. Selain itu tingginya logam berat $\mathrm{Pb}$ pada sedimen di LPS-I karena lokasi ini merupakan titik pertemuan antara empat aliran yaitu yang berasal dari pelabuhan, perairan pesisir pantai makam keramat, selat Lombok dan muara Dusun Cemara serta lebih dekat dengan pemungkiman warga.

Kandungan logam berat pada ketiga stasiun masih dalam kisaran di bawah 85 $\mathrm{mg} / \mathrm{kg}$ sehingga masih berada pada level target menurut IADC/CEDA, 1997. Jika konsentrasi kontaminan yang ada pada sedimen memiliki nilai yang lebih kecil dari nilai level target, maka substansi yang ada pada sedimen tidak terlalu berbahaya bagi lingkungan. Namun logam berat yang mengendap pada sedimen dapat kembali masuk ke badan perairan karna proses kimiafisika sehingga dapat membahayakan hidup biota laut (Tabel 1). Menurut Kadang (2005), logam berat dalam perairan mempunyai waktu paruh $32 \times 10^{3}$ tahun dan sedimen $2,5 \mathrm{x}$ $10^{8}$ tahun lebih lama dibandingkan dengan logam berat yang berada di daratan dan di udara. Karena waktu tinggal logam berat pada sedimen sangat lama, maka sedimen yang tercemar dengan logam berat seperti $\mathrm{Pb}, \mathrm{Cd}$ dan $\mathrm{Cu}$ akan berpotensi berperan sebagai sumber pelepasan kembali ke air laut dan pelepasan ini tergantung pada $\mathrm{pH}$ air laut.

Tabel 1. Hasil pengukuran parameter fisikakimia perairan pada tiap stasiun pengamatan.

\begin{tabular}{|c|c|c|c|c|c|c|c|c|c|c|}
\hline \multirow{3}{*}{ No } & \multirow{3}{*}{ Parameter } & \multicolumn{3}{|c|}{ Stasiun 1} & \multicolumn{3}{|c|}{ Stasiun 2} & \multicolumn{3}{|c|}{ Stasiun 3} \\
\hline & & \multicolumn{3}{|c|}{ Pengambilan ke- } & \multicolumn{3}{|c|}{ Pengambilan ke- } & \multicolumn{3}{|c|}{ Pengambilan ke- } \\
\hline & & I & II & III & I & II & III & I & II & III \\
\hline 1. & $\begin{array}{l}\text { Kedalaman } \\
\text { perairan ketika } \\
\text { surut }(\mathrm{cm})\end{array}$ & $0-33$ & 0.3 & 0.7 & 0.48 & $0-4$ & 0.8 & $0-12$ & $0-3$ & $0-9$ \\
\hline 2. & $\begin{array}{l}\text { Kedalaman } \\
\text { perairan ketika } \\
\text { Pasang }(\mathrm{cm})\end{array}$ & $30-126$ & $32-122$ & $36-119$ & $45-153$ & 53-151 & 53-158 & 34.78 & $36-86$ & $34-71$ \\
\hline 3. & Suhu ( $\left.{ }^{\circ} \mathrm{C}\right)$ & 32 & 31 & 33 & 30 & 32 & 31 & 28 & 30 & 29 \\
\hline 4. & $\begin{array}{l}\text { Fraksi sedimen } \\
(\%)\end{array}$ & $\begin{array}{l}\text { - Pasir } \\
\text { - Debu } \\
\text { - Liat }\end{array}$ & $\begin{array}{l}: 80 \% \\
: 16.67 \% \\
: 3.33 \%\end{array}$ & & $\begin{array}{l}\text { - Pasir } \\
\text { - Debr } \\
\text { - Liat } \\
\end{array}$ & $\begin{array}{l}: 73.33 \% \\
: 23.34 \% \\
: 3.33 \% \\
\end{array}$ & & \begin{tabular}{|l} 
- Pas \\
- Del \\
- Lia
\end{tabular} & $\begin{array}{l}\text { sir }: 6.67 \% \\
\text { bu : }: 20 \% \\
\text { at }: 73.33 \%\end{array}$ & \\
\hline \multicolumn{11}{|c|}{ Kimia } \\
\hline 1. & $\mathrm{Ph}$ & 8 & 8 & 8 & 8 & 8 & 8 & 8 & 8 & 8 \\
\hline 2. & $\begin{array}{l}\text { Salinitas } \\
(\mathrm{ppm})\end{array}$ & 31.04 & 32.35 & 32.05 & 32.57 & 34.23 & 32.98 & 30.9 & 29.53 & 30.04 \\
\hline
\end{tabular}
perairan pantai Labuhan Tereng Kabupaten Lombok Barat, diantaranya yaitu Anadara granosa, Anadara antiquata, dan Anadara cornea (gambar 3). Kerang darah yang memiliki kandungan $\mathrm{Pb}$ tertinggi terdapat pada

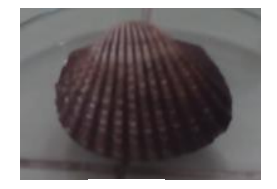

A

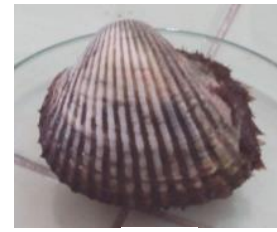

B

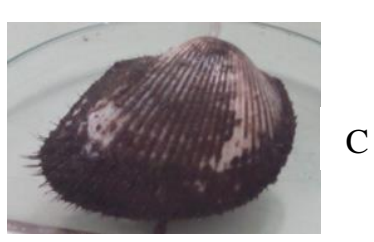

Gambar 3. A: Anadara granosa, B: Anadara cornea, $\mathrm{C}$ : Anadara antiquata

spesies A. antiquata $(13.075 \mathrm{mg} / \mathrm{kg})$ dan A. granosa di LPS-III $(9.43 \mathrm{mg} / \mathrm{kg})$. Kerang yang memiliki kandungan $\mathrm{Pb}$ terendah terdapat pada spesies A. antiquata $(0.57$ $\mathrm{mg} / \mathrm{kg}$ ) di LPS-II (Gambar 4). Tingginga kadar $\mathrm{Pb}$ pada A. antiquata dah A. granosa pada LPS-III disebabkan oleh struktur sedimen pada LPS-III yang dominan lumpur (Tabel 1). Hasil penelitian Rudiyanti (2009), menyatakan walaupun kadar logam berat pada 
sedimen memiliki kadar lebih rendah, namun tingkat akumulasi logam berat oleh kerang darah lebih tinggi. Hal ini berkaitan erat dengan struktur sedimen.

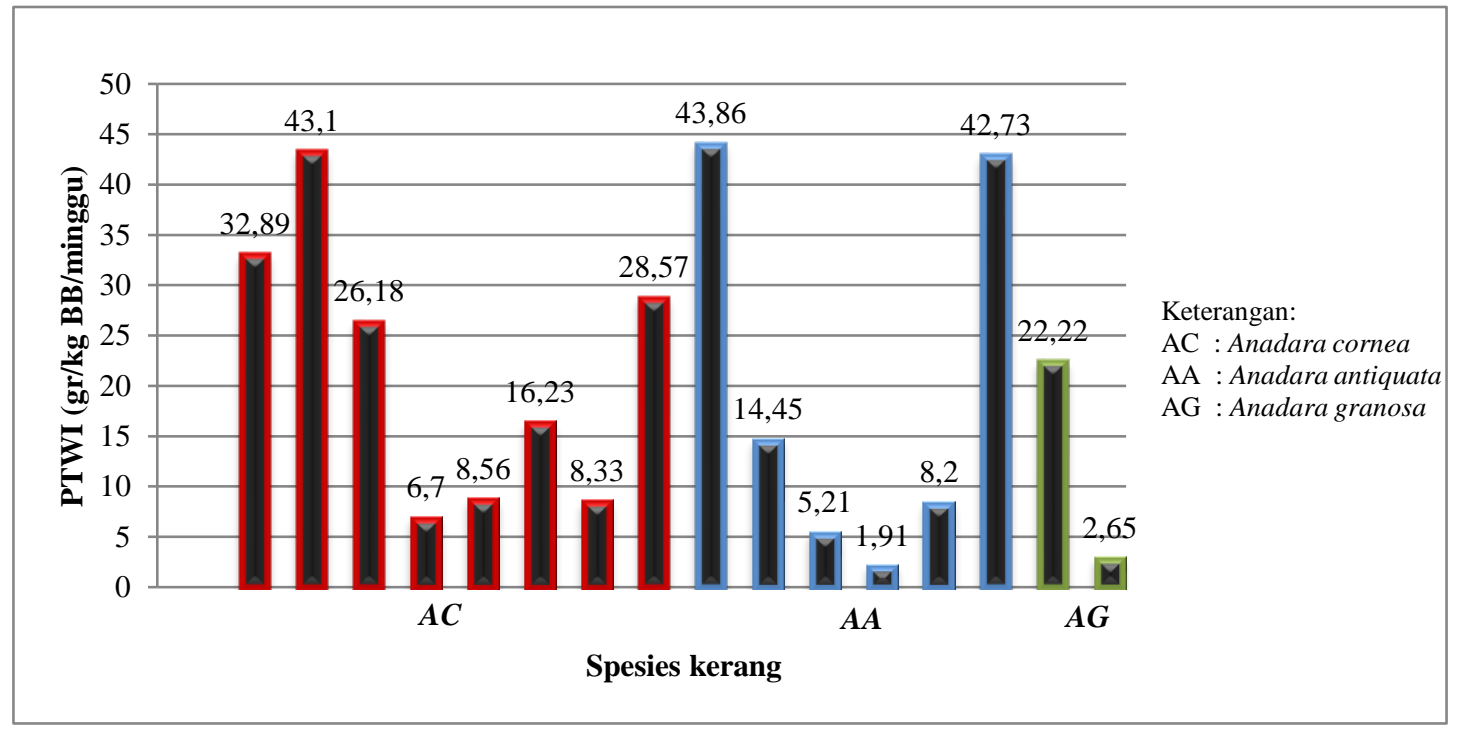

Gambar 4. A: Grafik kandungan Pb pada kerang darah di LPS-I, LPS-II, dan LPS-III

Didukung oleh pernyataan Amriani (2011), bahwa sedimen dengan kandungan lumpur (debu) yang tinggi akan meningkatkan bioakumulasi logam berat. Selain itu tingkat akumulasi dapat disebabkan oleh salinitas pada suatu perairan. Salinitas yang relatif rendah pada LPS-III dapat meningkatkan bioakumulasi logam berat $\mathrm{Pb}$. Hal ini sesuai dengan pernyataan Siregar (2009), tingkat akumulasi logam berat akan semakin besar jika nilai salinitas rendah tetapi akuı B logam berat akan semakin kecil apabila salinitas lebih besar. Hal ini disebabkan perubahan salinitas dapat mempengaruhi kelangsungan hidup, pertumbuhan dan metabolisme fisiologi dari organisme laut.

Berdasarkan hasil pengamatan pada ketiga spesies kerang darah yang memiliki ukuran $>2 \mathrm{~cm}$ dan $<3.5 \mathrm{~cm}$ memiliki tingkat akumulasi logam berat lebih tinggi dibandingkan kerang darah yang memiliki ukuran $>3.5 \mathrm{~cm}$. Hal ini dapat disebabkan oleh kemampuan kerang darah ukuran besar dan kecil dalam mengakumulasi logam berat $\mathrm{Pb}$. Hal ini sesuai dengan pernyataan Rudiyanti, (2009) bahwa umur kerang darah juga dapat mempengaruhi rendahnya konsentrasi logam berat yang ada di dalam tubuh kerang darah, dimana semakin besar ukuran kerang darah maka kandungan logam berat akan menurun. Kerang Darah yang berukuran kecil (muda) memiliki kemampuan akumulasi yang lebih besar dibandingkan dengan kerang yang berukuran lebih besar (tua). Semakin besar ukuran (tua) kerang maka akan semakin baik kemampuannya dalam mengeliminasi logam berat. Aunurohim (2008), bahwa pada saat proses metabolisme mencapai puncaknya, maka kebutuhan akan logam berat juga semakin 
meningkat. Hal inilah yang memungkinkan konsentrasi logam berat pada kerang lebih tinggi pada saat masa produktif (ukuran sedang) dibandingkan pada kerang yang berukuran kecil dan besar.

Berdasarkan hasil pengukuran kadar $\mathrm{Pb}$ dari 16 kerang darah yang menjadi sampel $56.25 \%$ atau sebanyak 9 kerang sudah melampaui nilai ambang batas maksimum cemaran logam berat dalam pangan. Menurut Standar Nasional Indonesia/SNI (2009) menyatakan bahwa ambang batas maksimum cemaran logam berat $\mathrm{Pb}$ pada kekerangan (bivalve) yaitu sebesar $1.5 \mathrm{mg} / \mathrm{kg}$. Sehingga dapat disimpulkan bahwa kerang darah yang terdapat pada perairan Pantai labuhan tereng kabupaten Lombok barat sudah kurang baik untuk dikonsumsi secara berlebihan.

Menurut Standar Nasional Indonesia/SNI (2009), jika terkena paparan timbal secara berlebih dapat menyebabkan:

1. Pada bayi dan anak-anak akan menyebabkan kerusakan otak, menghambat pertumbuhan, kerusakan ginjal, gangguan pendengaran, mual, kehilangan nafsu makan, gangguan pada kecerdasan dan tingkah laku.

2. Pada orang dewasa dapat menyebabkan peningkatan tekanan darah dan gangguan pencernaan, kerusakan ginjal, keruskan syaraf, sulit tidur, sakit otak dan sendi, perubahan mood dan gangguan reproduksi

Berdasarkan Badan Standardisasi

Nasional (SNI 7387:2009) tentang batas maksimum cemaran logam berat dalam pangan dan CODEX STAN 193-1995 tahun 2007 mengenai standar CODEX untuk kontaminan dan toksik pada makanan, bahwa nilai PTWI (Provisional Tolerable Weekly Intake/Asupan yang ditoleransi untuk seminggu) sebesar $0.025 \mathrm{mg} / \mathrm{kg}$ untuk logam $\mathrm{Pb}$. Penentuan batas aman konsumsi bertujuan untuk mengetahui batas konsumsi kerang darah yang telah tercemar logam berat $\mathrm{Pb}$ sehingga tidak membahayakan kesehatan dengan mengacu pada baku mutu yang telah ditetapkan. Batas aman konsumsi kerang darah dapat dilihat pada gambar 5 .

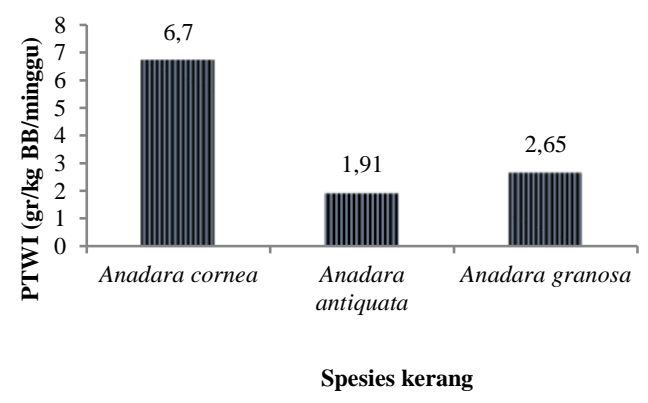

Gambar 5. Batas aman konsumsi kerang darah per minggu di Perairan Pantai Labuhan Tereng Kabupaten Lombok Barat

Penentuan batas aman konsumsi bertujuan untuk mengetahui batas konsumsi kerang darah yang telah tercemar logam berat $\mathrm{Pb}$ sehingga tidak membahayakan kesehatan dengan mengacu pada baku mutu yang telah ditetapkan. Berdasarkan hasil penelitian, batas aman pada masing-masing jenis kerang darah berbeda-beda. Batas aman konsumsi A. cornea dalam waktu satu minggu yaitu berkisar antara 6.7-43.1 gr/kg BB/minggu, A. antiquata berkisar antara 1.91-43.86 gr/kg 
BB/minggu, sedangkan A. granosa berkisar antara 2.65-22.22 gr/kg BB/minggu (Gambar $5)$.

Nilai batas aman konsumsi untuk setiap orang berbeda tergantung berat badan dan kondisi tubuh setiap orang. Jika diasumsikan berat badan seseorang adalah $50 \mathrm{~kg}$ maka kelayakan konsumsi kerang darah untuk spesies A. cornea tidak boleh lebih dari 3352155 gr/minggu, A. antiquata tidak boleh lebih dari 95.5-2193 gr/minggu, dan A. granosa tidak boleh lebih dari 132.5-1111 gr/minggu.

Penetapan tingkat kelayakan konsumsi pada kerang darah ini bertujuan untuk meminimalkan dampak negatif yang diperoleh dari kerang darah yang sudah tercemar logam berat $\mathrm{Pb}$ pada manusia yang ingin mengkonsumsinya. Selain dengan mengatur pola konsumsi kerang darah, cara mengolah kerang darah sebelum dikonsumsi juga sangat penting. Berdasarkan hasil penelitian Nisma dkk (2012) Perendaman daging kerang hijau dalam perasan air jeruk nipis sangat efektif menurunkan kadar logam berat $\mathrm{Pb}$ dalam daging kerang. Sedangkan berdasarkan penelitian Sari dkk (2014) perebusan kerang darah dengan menggunakan larutan jeruk nipis dapat menurunkan kadar logam berat $\mathrm{Pb}$ sebesar 59.33\%, sedangkan pada perebusan selama 30 menit dapat menurunkan kadar $\mathrm{Pb}$ hingga 60.67\%, dan pada perebusan hingga 45 menit dapat menurunkan kadar Pb hingga 63.33\%.

\section{KESIMPULAN}

Logam berat $\mathrm{Pb}$ pada sedimen tertinggi terdapat pada LPS-I $(30.66 \mathrm{mg} / \mathrm{kg})$, namun kisaran kadar $\mathrm{Pb}$ pada sedimen di LPS-III masih berada pada level target menurut IADC/CEDA, 1997. Kandungan logam berat $\mathrm{Pb}$ tertinggi terdapat pada spesies A. antiquata $(13.075 \mathrm{mg} / \mathrm{kg})$ di LPS-III dan dari 16 sampel kerang darah $56.25 \%$ sudah melampaui nilai ambang batas maksimum cemaran logam berat dalam pangan menurut SNI (2009). Batas aman konsumsi kerang darah spesies A. cornea yaitu 335-2155 gr/minggu, A. antiquata yaitu 95.5-2193 gr/minggu, dan A. granosa yaitu 132.5-1111 gr/minggu.

\section{DAFTAR PUSTAKA}

Amin, B., Evy, A., Mikel, A.S. 2011. Distribusi Spasial Logam Pb Dan Cu Pada Sedimen Dan Air Laut Permukaan Di Perairan Tanjung Buton Kabupaten Siak Provinsi Riau. Teknobiologi, II: 1-8.

Amriani, Boedi, H., Agus H. Bioakumulasi Logam Berat $(\mathrm{Pb})$ dan Seng $(\mathrm{Zn})$ Pada Kerang Darah (Anadara granosa L.) dan Kerang Bakau (Polymesoda begalensis L.) Di Perairan teluk Kendari. Ilmu Lingkungan 9: 45-50.

Aunurohim, G. Radenac, D. Fichet., 2006. Konsentrasi Logam Berat pada Makrofauna Bentik di Kepulauan Kangean Madura. Berkala Penelitian Hayati. 12 (1): 79-85.

Connell DW \& GJ Miller. 1995. Kimia dan Ekotoksikologi Pencemaran. Penerjemah; Yanti Koestoer; 
pendamping, Sahati. UI-Press. Jakarta.

IADC/CEDA. 1997. Convetion, codes, adnd conditions: Marine disposal. Enviromental aspects of dredging 2a. hal 71.

Kadang, L. 2005. Analisis Status Pencemaran Logam Berat $\mathrm{Pb}, \mathrm{Cd}$ Dan $\mathrm{Cu}$ Di Perairan Teluk Kupang Provinsi Nusa Tenggara Timur. Thesis S2. Institut Pertanian Bogor.

Lubis, H. dan Challkuddin, A. 2008. Pemeriksaan Kandungan Logam Merkuri, dan Kadmium dalam Daging Rajungan Segar yang Berasal dari TPI Gabion Belawan Secara Spektrofotometri serapan Atom. Kedokteran Nusantara 41: 39-47.

Manahan, S.E. 2000. Environmental Chemestry (Seventh Edition). Boca Raton: CRC Press LLC.

Nisma, F., Almawati, S., dan Halifah, W.A. 2012. Efektifitas Air Perasan Buah Jeruk Nipis (Citrus aurantifolia Cristm. \& Panzer Swingle) Terhadap Penurunan Kadar Logam Timbal $(\mathrm{Pb})$, Cadmium $(\mathrm{Cd})$, dan Tembaga $(\mathrm{Cu})$ pada Daging Kerang Hijau (Perna viridis L). FarmaSains Vol 1 No5 :209215.

Nurjannah, Hartanti, R.R., Nitibaskara. 1999. Analisa Kandungan Logam Berat $\mathrm{Hg}$, $\mathrm{Cd}, \mathrm{Pb}$, As dan $\mathrm{Cu}$ Dalam Tubuh Kerang Konsumsi. Buletin THP 1: 58.

Payung, F.L., Ruslan, Agus, B.B. 2013. Studi Kandungan Dan Distribusi Spasial Logam Berat e $(\mathrm{Pb})$ Pada Sedimen Dan Kerang (Anadara sp) Di Wilayah Pesisir Kota Makasar. Fakultas Kesehatan Masyarakat UNHAS: 110.

Rudiyanti, S. 2009. Biokonsentrasi Kerang Darah (Anadara granosa linn)
Terhadap Logam Berat Cadmium (Cd) Yang Terkandung Dalam Media Pemeliharaan Yang Berasal Dari Perairan Kaliwungu. Seminar Nasional. Jurusan Perikanan, Fakultas Perikanan dan Ilmu Kelautan, Universitas Diponegoro. Di seminarkan di semarang 22 Februari tahun 2009 pada seminar Expo.

Sari, K.A., Putut, H.R., dan Apri, D.A. 2014. Pengaruh Lama Perebusan Dan Konsentrasi Larutan Jeruk Nipis (Citrus Aurantifolia) Terhadap Kadar Timbal (Pb) Dan Kadmium (Cd) Pada Kerang Darah (Anadara Granosa). Pengolahan dan Bioteknolgi Hasil Perikanan Vol 3, No 2: 1-10.

Siaka, I.M. 2008. Korelasi Antara Kedalaman Sedimen Pelabuhan Benoa Dan Konsentrasi Logam Berat $\mathrm{Pb}$ Dan Cu. Kimia 2: 61-70.

Siregar, Y.I. 2009. Bioakumulasi Kadmium Pada Kerang Hijau (Perna viridis) Dengan Aplikasi Perunut Radioaktif. Biologi Indonesia 6(1): 39-50.

SNI 7387: 2009. Batas Maksimum Cemaran Logam Dalam Pangan. Badan Standar Nasional. ICS 67.220.20.

Tampubolon, H.s., Darma, B., Indra, L. 2013. Studi Kandungan Logam Berat Tembaga $(\mathrm{Cu})$ Dan $(\mathrm{Pb})$ Di Perairan Danau Toba, Provinsi Sumatera Utara. Universitas Sumatera Utara.

Umbara, H. dan Heni, S. Faktor Bioakumulasi 210Pb Oleh Kerang Darah (Anadara Granosa). Hasil Penelitian dan Kegiatan PLTR: 62-70.

Wahab, A dan Mutmainnah. 2005. Analisis Kandungan Logam Berat Dan Seng Di Sekitar Perairan Pelabuhan ParePare Dengan Metode Adisi Standar. Marina Chimica Acta 6: 21-24. 